\title{
WRONGFUL LIFE: THE LIMITS OF LIABILITY AND BEYOND
}

\author{
CARel J. J. M. Stolker*
}

\section{A WRONGFUL LIFE}

ON 24 February 1977 a severely handicapped girl was born in West Germany. Her condition was due to a rubella (German measles) infection caught by her mother in the first weeks of pregnancy. The gynaecologist who had treated the mother was at fault in that he had not at the time drawn the mother's attention to the illness and its dangers. If the woman had been aware of the risks she would - and this was certain - have had an abortion performed.

The doctor was faced with two claims for damages: one from the mother, claiming the extra costs for bringing up a handicapped child, and one from the child described on the basis of an American example as a "wrongful life" claim. ${ }^{1}$ The claim by the girl against the doctor was for compensation of all damage she had suffered as a result of the rubella infection. The Bundesgerichtshof (German Supreme Court) admitted the mother's claim; however, it rejected the girl's. The significant consideration in the judgment was "that in cases like the present the limits have definitely been reached and overstepped within which a legal claim is acceptable". ${ }^{2}$

Is it then true that here, in the case of the wrongful life claim, the limits of liability law have been reached? ${ }^{3}$

\footnotetext{
* Carel Stolker, University of Leiden, the Netherlands, has been a visiting professor of law at the University of California, Hastings College of the Law, during the 1991 spring semester. He is grateful to Academic Dean Mary Kay Kane, and to Professor David I. Levine, both of Hastings, and to David Hansen, at that time third-year student at Hastings, for very helpful comments.
}

1. The father had also brought a claim, but for brevity's sake I will not deal with that. The mother's claim, known as the "wrongful birth" claim, is likewise disregarded here. For that particular claim see e.g. C. R. Symmons, "Policy Factors in Actions for Wrongful Birth" (1987) 50 M.L.R. 269 et seq.; Gerald Robertson, "Wrongful Life" (1982) 45 M.L.R. 697 et seq.; Andrew Grubb, "Medical Law-Failure of Sterilisation-Damages for 'Wrongful Conception' " (1985) 44 C.L.J. 30 et seq.; and Lexa Hilliard, " 'Wrongful Birth': Some Growing Pains" (1985) 48 M.L.R. 224 et seq.; also, my dissertation Aansprakelijkheid van de arts, in het bijzonder voor mislukte sterilisaties ("Liability of the Doctor, Especially with Regard to Unsuccessful Sterilisation") (1988; in Dutch, summaries in English, French and German).

2. Bundesgerichtshof $18 \mathrm{Jan} .1983$, Juristenzeitung (1983), p.450: “dass in Fällen wie dem vorliegenden überhaupt die Grenzen erreicht und überschritten sind, innerhalb derer eine rechtliche Anspruchsregelung tragbar ist".

3. In the US that limit had already been reached earlier: Zepeda v. Zepeda 41 Ill.App.2d 240, 190 N.E.2d 849 (III. 1963). The claim is also referred to as a "dissatisfied life claim". 
One year later, in England, a similar case was brought before the Court of Appeal. Here, too, the plaintiff was born severely disabled. She claimed compensation for negligence from the doctor and the health authority. During pregnancy, her mother also had German measles. The infection, though, was not diagnosed. Like the German court, the English Court of Appeal ruled that a child has no right of action for "wrongful life" ${ }^{4}$ Doctors are not under a legal obligation to the foetus to terminate its life nor has a foetus a legal right to die. ${ }^{5}$ The Court's rejection of the claim was predictable. McKay was decided under common law, but the same principle would apply under the Congenital Disabilities (Civil Liability) Act 1976, which was passed as a result of the Law Commission's Report on Injurtes to Unborn Children. ${ }^{6}$ The Law Commission's intention was to preclude an action for wrongful life. The question whether there should be a claim for "wrongful life" was considered to be a difficult one "which has caused us much concern". The Commission came to the conclusion that no cause of action should lie:

Such a cause of action, if it existed, would place an almost intolerable burden on medical advisers in their socially and morally exacting role The danger that doctors would be under subconscious pressures to advise abortions in doubtful cases through fear of an action for damages is, we think, a real one It must not be forgotten that in certain circumstances, the parents themselves might have a claim in negligence.

In the German case the Bundesgerichtshof ruled:

If such a claim by the child against the doctor is considered acceptable, then one would for instance also have to accept a hability on the part of parents who, in spite of severely adverse genetic circumstances, have decided to have a child (and thus burdened not only themselves but also others with extra costs). All this makes it clear that the civil law has indeed reached its limits, so that a more far-reaching cause of action must be forgone A cause of action in cases of this type is no longer feasible or meaningful. ${ }^{7}$

4 McKay v Essex Area Health Authorty [1982] Q B 1166, [1982] 2 W L R 890

5 Several comments have been written e g Charles Lewis, "The Quality of Life" (1982) L. S Gaz 839, Robertson, op cut supra n 1, at pp 697 et seq, Symmons, op cat supra n 1, at pp $269 \mathrm{et}$ seq

6 Report on Injuries to Unborn Children, Cmnd 5709 (1974) The Act, though, is a very complex one it "has to be seen to be believed", according to Street on Torts (9th edn, Margaret Bra/ıer (Ed), 1993), p 196 Under s 1(2)(b), a cause of action accrues, tnter alta, if the mother is affected during her pregnancy so that the child is born "with disabilities which would not otherwise have been present" It is still unclear whether or not the Act also applies to wrongful life claims It is possible to argue that the issue of wrongful life with all its ethical and moral implications remains open for review by the House of Lords Street, ibid See, however, also Salmond and Heuston on the Law of Torts (20th edn, R F V Heuston and R A Buckley (Eds), 1992), p 430 "Such an action for 'wrongful lite' did not exist before the Act, and almost certainly does not exist now" (footnote omitted)

7 A good article on the "wrongful life clam" is by the Belgian author R Kruithof, "Schadevergoeding wegens de geboorte van cen ongewenst kınd?" (1986-1987) Rechtskundig Weekblad 2737 et seq (in Dutch) 
But, why is it that liability "in cases of this type is no longer feasible or meaningful"? Surely, this cannot involve a new liability requirement beyond the standard hurdles of duty, breach, causation and damage. To avoid liability, simply referring to possible future, completely different cases must not be allowed to be the decisive argument in the debate before the judge. The basic principles (dogmatics) of tort law ought to be adhered to; in this and in any other type of case. ${ }^{8}$

Such a debate will, in the eyes of non-lawyers-in this case the victim and the doctor-be conducted in an unpleasant "tone". The child's lawyer will have to support his claim by postulating that it would have been better if the girl had not been born. Obviously she is not interested in the remedy of the cost of suicide, ${ }^{9}$ but in the wish to live out the rest of her life without cares, at least financially. But would it be enough for the girl's attorney to ignore the dogmatics of tort law and plead solely for a socially acceptable solution? ${ }^{10}$

On the other hand, the doctor's lawyer must be required to indicate that one or more of the requirements for liability have not been fulfilled. Here, too, it is not sufficient for him to appeal in abstract terms to "the limits of liability law" by referring to other possible cases in the distant future. To put it differently: the limits to liability law are not determined in the first instance by the bounds of our imagination or the bounds of our sense of what is "reasonable" but by the boundary markers of duty, breach of duty, causation and damage."

8 Cf J H Nieuwenhuis, "Pleldool voor een dogmatische rechtswetenschap" (1987) R M Themis 1 (in Dutch)

9 Put in crude terms, the price of a bottle of pills

10 This is what Schoordijk does in his article in a Festschrift for Rood-de Boer, Met het oog op het belang van het kind (1988), pp 129 et seq (in Dutch) See also the prelimnary recommendations of the Verenging voor Gezondheidsrecht by J K M Gevers, Juridische Aspecten van erfelljkheidsonderzoek en advies (1987), pp 21 et seq (1n Dutch) He (like other authors) is slightly too optımistic when he refers (idem, p 25) to a "growing willıngness of American judges" to find in favour of wrongful life claums I can see no question of this in the case law E $\mathrm{g}$ the case that he quotes, Azzolino v Dingfelder $71 \mathrm{~N}$ C App 289,322 S E 2d 567 (1984), has been quashed by the Supreme Court of North Carolna, 315 N C 103, 337 S E 2d 528 (1985) The claim was awarded in only a few cases Park v Chessin 60 A D 2d 80, $400 \mathrm{~N}$ Y S 2 d 110 (1977) (kidney disease), Becker v Schwartz 46 N Y 2d 401, 413 N Y S 2d 895, 386 N E 2d 807 (1978) (Down's syndrome), Turpin v Sortmi 31 Cal 3d 220,643 P 2d 954, 182 Cal Rptr 337 (1982) (deafness) The Supreme Court of Calıfornia awarded compensation only for certam material damages This latter ruling set aside the much more generous Curlender verdıct Curlender v Bio-Science Laboratories 106 Cal App 3d811, 165 Cal Rptr 477 (1980) (Tay-Sachs disease) See also another Calıfornan case Nandinı Gamı v Mullikın Medical Center Daily Appcllate Rep, Sept 1993, 11565 (tallure to disclose information) (an application of the Turpin rule) This all looks slightly different in the legal literature There the claim is usually advocated

11 In the US, unlike the civil law countries, there can be the additional complication of "jury nullification" a jury ignoring its instructions and returning a verdict against the law, usually to soften the effect of what the jurors regard as an unfaur legal doctrine See e $\mathrm{g} A$ Scheflin and J Van Dyke, "Jury Nullification the Contours of a Controversy" (1980) 43(4) Law \& Contemp Probs 51 
An appeal-whether or not emotional- to the limits of liability law is mainly heard in cases involving medical liability and then mainly from health-care workers. In, say, traffic liability law-whose significance, at least in Europe, within society is much bigger-such an appeal is heard much less frequently. Why is this?

One reason may be that doctors do their work specifically with a view to curing their patients. Unlike the normal situation on the roads, therefore, mistakes are not made by doctors working entrrely in their own interest. Another difference is that the parties to a medical claim usually know each other beforehand; the doctor-patient relationship is regarded as a prime example of a relationship of trust. In the case of medical errors, a claim for compensation by the patient severely disrupts that relationship of trust, even more than the error itself. An additional factor is that the doctor makes the error directly in the performance of his profession. Consequently, it is quite understandable that he regards any claim as a direct attack on his professional honour.

Also of great importance in this context is the fear of "American-type claims". Doctors are afraid that the situation in the New World represents their future, with its series of court actions, premium increases and "defensive medicine". ${ }^{12}$ This, perhaps, is the reason for the appeal to the limits of liability.

\section{THE WRONGFUL LIFE CLAIM}

THE "wrongful life claim" category comprises numerous, highly difterent types of cases. Invariably, however, they relate to the claim of the handicapped child. A few examples taken from American case law include a careless medical treatment of the mother before conception; ${ }^{13}$ careless genetic advice prior to ${ }^{14}$ or during pregnancy; ${ }^{15}$ careless sterilisation of a patient, specifically aimed at preventing the birth of a handicapped child $;{ }^{16}$

12 See e g Peter E Herzog, "The Reform of Medical Liability Tort Law or Insurance" (1990) 38 A J Comp L 99 and my book about the American medical malpractice crisis Van arts naar advocaat-Aansprakelykheud voor medische fouten in Amertka (1989) (in Dutch)

13 Eg Renslow v Mennonite Hospttal 67 Ill 2d 348, 367 N E 2d 1250 (1977) (wrong blood transfusion nine years before conception), Albala $v$ City of New York $54 \mathrm{~N}$ Y $2 \mathrm{~d} 269$, 445 N Y S 2d 108, 429 N E 2d 786 (1981) (perforated uterus four years before conception)

14 Eg Park v Chessin, supra n 10 (serious kidney disease), Moores v Lucas Fla App 1981, 405 So 2d 1022 (1981) (Larsen's syndrome) and Curlender, supra n 10 (TaySachs disease)

15 E g Procanic v Cillo 97 N J 339, 478 A 2d 755 (1984) (rubella), Berman v Allan 80 N J 421, 404 A 2d 8 (1979) (Down's syndrome)

16 Eg Speck v Finegold $497 \mathrm{~Pa} 77,439$ A 2d 110 (1981) In this case a sterlisation error had been made first, then the abortion was unsuccessful and was followed by the birth of a severely handicapped child (neurofibromatosis) And to think how students sometimes scoff at the "improbable" cases set for preliminary exams nothing is as strange as reality" 
careless prescribing of medicines-whether or not of poor quality-during pregnancy $:{ }^{17}$ and other careless actions during pregnancy ${ }^{18}$

The wrongful life claim is regarded in America as the frontier of medical malpractice litigation. The principal reason it is becoming more and more common is that the market for "genetic counselling" is rapidly growing. While the West German case described earlier involved the failure to identify rubella or the risks there of (there have also been rubella claims in the United Kingdom and the United States), the majority of the American verdicts relate to faults in genetic counselling.

Some wrongful life claims are easier to assess than others. For instance, a doctor who improperly administers medication to a pregnant woman, injuring an otherwise healthy child before its birth, is directly liable to the child..$^{19}$ The doctor is the one who caused the injury; similarly, a careless driver of an automobile who collides with and injures a pregnant woman also commits a tort towards her unborn child.

Assessment, however, becomes much more difficult in the rubella cases and in the cases involving incorrect genetic counselling. Here, there is no question of causing injury to a healthy child. However, the reproach that is made to the doctor in such cases is that he has wrongly deprived the parents of the possibility of abortion or, in the case of careless genetic counselling prior to conception, that he has deprived the parents of the possibility of deciding not to have children. These, the "much more difficult" cases, form the central focus of the present article.

\section{A RIGHT TO BE ABORTED?}

THE postulate put forward by the child-plaintiff is as follows: "You, the doctor, ought to have given my mother the opportunity of having me aborted. My life is not worth living; I would prefer no life to the life I have." It sounds like Job who, when tested by God as a trial of strength against the Devil, said: "Let the day perish wherein I was born ... Let that day be darkness." 20

Earlier on, I pointed out that the child is not making a claim for "specific performance" (i.e. death), but a claim for compensation of damages. The liability law compels her to contest her own existence. The Bundesgerichtshof ruled that negligence had been committed as against the

17. E.g. Grodin v. Grodin 102 Mich.App. 396, 301 N.W.2d 869 (1980) (father and slightly handicapped son (brown teeth) claim against mother and doctor for physical damage resulting from use of medicines during pregnancy).

18. E.g. Bergstreser v. Mitchell 577 F.2d 22 (1978) (carelessly performed Caesarean section).

19. See e.g. Burton v. Islington Health Authority [1993] Q.B. 204, [1992] 3 All E.R. 833; de Martell v. Merton and Sutton Health Authority [1992] 3 All E.R. 820.

20. Job 3: 3-4. 
mother and that she was entitled to damages, but that the situation was different for the child: ${ }^{21}$

A direct delictual obligation to prevent the birth of a foetus on account of the fact that the child will presumably be born with defects which, from the point of view of society or from its own presumed view (as to which there is, by nature, not the slightest clue), would make its life seem "not worth living", would by necessity constitute an alien element within the sphere of delictual standards of conduct which are generally focused on protecting the integrity of human life. Such an obligation does not exist.

Indeed, in the court's view, the mother can enter into an abortion agreement with the doctor; but, in such an agreement, the child is no more than a passive object. The child does not have a right to be aborted and thus cannot impose upon the doctor any legal obligations. ${ }^{22}$

The Bundesgerichtshof further adds that a judge who allows the child's claim will at the same time be giving a verdict on the value of the child's life: "For you, it would have indeed been better had you not been born." The court, with an explicit reference to "the experience of the judge-made law of the Federal Republic of Germany which has been tainted by the National Socialist reign of injustice", felt abhorrence that such rulings should ever have to be pronounced by judges.

The Dutch emeritus-professor Schoordijk pointed out that anyone who objects to this judgment would seem to be casting a morally discreditable light on himself. He argues, in line with contemporary social and ethical views, that life is a valuable possession, but one that is not inviolable under all circumstances. He therefore asks why the person who has to live with a severe handicap because the doctor has not pointed out to the mother the great risk of malformation and the alternative of having an abortion cannot reproach the doctor by saying: "You have harmed me in my human dignity. You negligently paid no heed to the fact that my mother-I could not speak for myself, which is why my mother had to do this for me-did not consider my life worth living; that is why you have violated my right, in as much as this is humanly possible, to be born in reasonable health."23

The question is: did the doctor violate a legal obligation towards the girl? The Bundesgerichtshof answers this question in the negative. No act of tort has been committed towards the child; neither a written nor an unwritten legal obligation exists that handicapped foetuses should be aborted. Nor does a right to be aborted result for the child from the contract between mother and doctor, "because the law currently in force

21. Supra n.2, at p.450.

22. See also Stephenson LJ, in McKay [1982] 2 W.L.R. 890, 902: "That duty may be owed to the mother, but it cannot be owed to the child."

23. Schoordijk, op. cit. supra n.10, at p.132. 
grants the mother the justifiable permission to terminate a pregnancy explicitly only where it is in her own interest". ${ }^{24}$

The right to request an abortion is vested solely in the mother, not in the child. Schoordijk rightly questions why this is so. Is it not true, he writes, that it is specifically the mother who is the person best qualified to assess the child's chances in life in the child's interest as she perceives it and to draw conclusions from this in the child's interest-about which each person may think differently but about which the mother is allowed to have an opinion? He adds: "Is not the child allowed to join that opinion; is it not imputed to the child?"25 Schoordijk goes no further than this, but he does quote the German annotator Deutsch, who described the ruling of the Bundesgerichtshof as "a paternalistic limitation of the protective right to the parents [which] seems strangely outmoded". ${ }^{26}$

Werr, in his comment on McKay, would appear to share Schoordijk's opınion: ${ }^{27}$

In the present case "no duty" is perhaps the weakest of these grounds To assert that one cannot owe a duty to a foetus to kill it is plausible enough, but the plausibility fades a bit when one has to admit that a duty to kill the foetus may well be owed to the mother. if the duty can be owed to one of the affected parties, why not to the other?

The question now is: how can the child, to use Schoordijk's words, "join that opinion"? ${ }^{28}$ No written or unwritten rule of law exists on the basis of which the doctor should abort handicapped foetuses. That basis is selfevident. But in this case more is involved: a contract has been made between the woman and the doctor. According to this contract the doctor, at least impliedly, undertook to inform the woman, in the light of her pregnancy, about her illness (rubella) and about the risks it bore upon the unborn child, who could be considered an intended beneficiary of the contract. A comparable situation exists in those cases in which the doctor has provided the prospective parents with incorrect advice during genetic counselling. Such advice is requested with a view to having children. ${ }^{29}$ The request of the parents is not in the abstract form of "take a look at my

24 Supra n 2, at p 450, also dismıssive were Stephenson and Ackner LJJ in the only UK wrongful life case (rubella) McKay [1982] 2 W L R 890, 900 et seq On this subject, see also Robertson, loc ct supra n 1, Lewis, loc cut supra n 5

25 Schoordijk, op cat supra n 10, at pp 133-134

26 E Deutsch, Juristenzettung (1983), p 451 r c

27 Tony Weir, "Wrongful Life-Nipped in the Bud" (1982) 41 C L J 227

28 One might also think in terms of a third-party stıpulation, or perhaps of an agreement to which the as yet unborn-perhaps not even conceived-child is a party via its mother None the less, such constructions-which are somewhat artificial-are beyond everyday reality in cases like this

29 Under Dutch law both a chuld in utero at the time the doctor provided negligent advice and a child conceived after the advice was provided would be considered intended beneficiaries of the contract between doctor and parent 
genes", but is made with the intention of preventing the birth of handicapped children.

This brings us to the topic of what the Dutch call the "requirement of relativity", 30 the Germans call "Schutznorm", and what in America and England is usually referred to as the "unforeseeable plaintiff". In a wrongful life case, there is a duty: in this case not an unwritten duty or a statutory one - as usually applies in the case of relativity — but a contractual duty. ${ }^{31}$ That duty must be allocated a certain protective scope. The law "does not recognise a duty in the air", as the English Lord Justice Greer once said. ${ }^{32}$ The requirement of "relativity" is firmly established in the New Dutch Civil Code: "There is no obligation to repair damage when the violated duty does not have as its purpose the protection from damage such as that suffered by the victim." ${ }^{33}$ So, not only must it be ascertained which elements of damage are covered by its protection but also who falls within the scope of its protection. To put it in English terms, whether the victim is a "foreseeable plaintiff". ${ }^{34}$ To whom does the doctor owe a duty of care? Obviously, it is owed to the mother, but does it also include the child? Is there also a duty owed to the child?

The contract the woman made with the doctor, besides being in her own self-interest, also included the interests of the child, however counter-

30. The Dutch word "relativiteit" refers to the relationship between the tortfeasor and the victim. There is a very interesting parallel concept in American tort law: see Cardozo $\mathrm{CJ}$ in Palsgraf v. Long Island Railroad Co. 248 N.Y. 339, 162 N.E. 99 (1928), who wrote: "The conduct of the defendant's guard, if a wrong in its relation to the holder of the package, was not a wrong in its relation to the plaintiff, standing far away. Relatively to her it was not negligence at all."

31. The doctrine of relativity normally occurs in cases of tort. Yet it sometimes also has a bearing in cases of contractual liability. Compare my dissertation, op. cit. supra n.1, at pp.60 et seq. and the dissertation by $G$. $H$. Lankhorst, De relativiteit van de onrechtmatige daad (1992; in Dutch, with summaries in English and German). See also Kruithof, op. cit. supra n. 7 , at p. 2750 .

32. Greer LJ in Bottemley v. Bannister [1932] 1 K.B. 476.

33. Para.6:163; the new code came into force on $1 \mathrm{Jan} .1992$. Recently a translation in both English and French was published: P. P. C. Haanappel and Ejan Mackaay, New Netherlands Civil Code-Patrimonial law/Nouveau Code Civil Neerlandais-le Droit Patrimoinal (1990).

34. See the important US case, Palsgraf, supra n.30, "a law professor's dream of an examination question": Prosser and Keeton on Torts (1984), p.285; see also, more elaborate, the discussion of the US view in Prosser, "Palsgraf Revisited" (1953) 52 Mich.L.Rev. 1, 3. In England Lord Atkin has had a tremendous influence on the topic of duty of care towards the plaintiff. He introduced what now is called the "Atkinian neighbour principle": "The rule that you are to love your neighbour becomes in law, you must not injure your neighbour; and the lawyer's question, Who is my neighbour? receives a restricted reply. You must take reasonable care to avoid acts or omissions which you can reasonably foresee would be likely to injure your neighbour. Who, then, in law is my neighbour? The answer seems to bepersons who are so closely and directly affected by my act that I ought reasonably to have them in contemplation as being so affected when I am directing my mind to the acts or omissions which are called in question": Donoghue v. Stevenson [1932] A.C. 562, 580. The words "unforeseeable plaintiff" do not seem completely appropriate, since they focus entirely on the person of the victim, whereas the words "relativiteit" and "Schutznorm" focus both on the person of the victim and the type of damages suffered by that victim. 
intuitive some people may consider this "protection of interests" to be. Therefore the protective scope of the duty is also extended to the unborn child. In respect of that child, a duty (i.e. a contractual duty) was violated as well..$^{35}$

Support for this idea can be found in the Dutch "stowaway" case, which is a very clear and beautiful example of the usefulness of a separate requirement for liability besides duty, breach and causation. Van den Akker went off the road in his delivery truck at a bend, the truck toppled over and came to rest against a tree. In the back of the truck, unbeknown to the driver, had been Jansen; Jansen had been flung out of the truck and was lying severely injured on the verge. The question was whether Van den Akker had now also committed an act of tort as against Jansen. In its ruling, applying to the doctrine of "relativity", the Dutch Supreme Court set out the following considerations: "that Van den Akker did not need to be mindful of the presence of people in the loading space of his vehicle and therefore also did not need to make allowance in his driving behaviour for any risks resulting therefrom for the well-being of such people". ${ }^{36}$

Regarding the question of whether Van den Akker's negligent driving behaviour was also an act of tort towards the stowaway, the Supreme Court held that the decisive factor was whether the perpetrator should have made allowance in his behaviour for the attendant danger and for the well-being of the stowaway. He will certainly have to make allowance for other road users, but not for a stowaway since the driver did not need to "be mindful" of him.

There is no reason that this criterion cannot also be applied in contractual wrongful life cases. The doctor also violates a legal obligation towards the child if he should have been mindful of its presence and of its interest as this is perceived by the mother. This may be the case because the mother has specifically consulted the doctor with a view to having children. But it may also be the case where he should have informed the mother of his own accord-for instance, in rubella cases.

\section{THE PROBLEM OF THE DAMAGE}

IF we now assume that the doctor is liable towards the child, the next question that arises is: what damage does the child suffer? At a first glance the answer to this question seems simple: all the damage that results from the handicap-in other words, medical costs, adaptation of the home, loss

35. As far as US law is concerned, this contractual duty obviously does not come from a bargain or arrangement, but should be implied in law. I am arguing for an expansion of traditional concepts. In the US, by analogy, contract limitations have been avoided and new theories of recovery developed in situations in which the contract is between parties having a special relationship (i.e. insurance). Similarly, the relationship here between mother, child and doctor deserves special treatment.

36. Hoge Raad 27 Jan. 1984, (1984) Nederlandse Jurisprudentie 536. 
of earnings, etc. Here, the present handicapped situation is compared with that of a healthy child in the same way that two situations are normally compared in order to assess the damage. There must always be some change for the worse, a "diminution". The "fixed comparison point" in all cases is the situation in which the duty has not been violated.

Upon closer examination, however, we come up against an unusual problem. Without a violation of the duty (e.g. correct information about the rubella disease, or correct genetic counselling), the child would not have existed. Even if a healthy child would have been born, it would have been a different child (i.e. because the parents had decided, after abortion of the "handicapped foetus", to have a second-and perhaps this time healthy - child).$^{37}$ But the handicapped girl who is the focus of this article would never have been born healthy. The cause of the handicap was not the doctor, but the rubella infection. The only reproach against the doctor is that the child was born with handicaps.

Here, there are two closely interrelated problems. The first is whether the judge, in using the "diminution" qualification as an element of damage, is making a value judgment on the life of a handicapped person as such. Many American judges who have studied the wrongful life claim seem to have had great difficulty with this question. In fact, is the judge not being forced to make the statement that the child's life has indeed become of less value or inferior? To quote a Jewish proverb, "Is not the worst life always better than the best death?" ${ }^{38}$ However, such a court decision seems in no way to imply any judgment on the value of human life as such. In the case of the wrongful life claim what is involved is living with handicaps. If the courts do permit the action, juries and the expert witnesses will have to give an opinion on this. In injury cases they do nothing else. In so many cases an opinion is given on the diminution of the material and nonmaterial conditions of the severely handicapped victims, both physically and emotionally, but that did not mean that anything was said about a diminution of the value of that life. This is not altered by the fact that in the wrongful life claim the child is forced by the rules of the game to compare its handicapped existence with non-existence.

37. Those interested in this problem should refer to D. Parfitt, Reasons and Persons (1984), chap.3.

38. E.g. in Gleitman v. Cosgrove 49 N.J. 22, 227 A.2d 689 (1967) -the claim was rejectedthe considerations were that it "is basic to the human condition to seek life and hold on to it however heavily burdened"; followed by a quotation from Theocritus: "For the living there is hope, but for the dead there is none." More details on this can be found in an articleinteresting in its own right-by the Americans J. Bopp, B. A. Bostrom and D. A. Mckinney, "The 'Rights' and 'Wrongs' of Wrongful Birth and Wrongful Life: A Jurisprudential Analysis of Birth Related Torts" (1989) 27 Duq.L.Rev. 461 et seq. In my opinion, however, the question is no longer of importance in assessing the damage. It has already been answered by the mother (see Part III). 
The second problem is much greater. Even assuming that we can speak of a "diminution" as an element of damage, we still have to ascertain the extent of that damage. To assess the damages, a comparison has to be made between handicapped life and non-life. For the child in fact had only one alternative to its handicapped life: non-existence. It should be borne in mind that the child was damaged not by the doctor but by rubella. What the doctor can be blamed for is that the child was born handicapped. What should not be allowed is a comparison between handicapped life and healthy life. That latter alternative has never existed for the child.

But how can non-life or non-existence be assessed? What is the "fixed comparison point" in this situation? The problem is that the child has no solid ground under its feet-in the same way as Baron von Münchhausen, who fell into the swamp while riding his horse. It is true that the Baron was able to pull himself out of the swamp by his wig; for that, he merits our eternal admiration. The girl, however, is not Baron von Münchhausen. Does this mean that the girl's claim should therefore be rejected?

On the other hand one may ask oneself whether this problem-that the damage cannot be assessed-is not an all too formalistic argument to send the girl home with. She experiences her suffering day in and day out; if the doctor had not made a mistake, she would never have suffered. Yet she is told that her claim is built on quicksand. "If my grief were thoroughly weighed and my calamity laid in the balances," we hear Job lamenting again, "it would be heavier than the sand of the sea." And still no compensation? Is there no way out of this?

The UK Law Commission also questioned whether, in rejecting the wrongful life claim, it was not attaching too much weight to "considerations of logic": "Law is an artefact and, if social justice requires that there should be a remedy given for a wrong, then logic should not stand in the way." 39

Erwin Deutsch, a famous German annotator, too, does not seem to be impressed by the power of logic. He strongly condemns the Alles-oderNichts Prinzip (all-or-nothing principle) applied by the Bundesgerichtshof. ${ }^{40}$ Deutsch advocates that the child should not be compensated for all costs of living but only for those costs which result from the handicap (the additional needs: Mehrbedarf). The central idea in his argument is that the law would be falling short if it could not come up with a solution. But, however sympathetic the aim may be-and whose sympathy does not lie with the child? - the damage problem does not seem to have been solved

39. Law Commission, op. cit. supra n.6, at p.34. Ultimately, the Commission rejects the claim after all, fearing an increasing number of abortions (see under Part V infra).

40. In my opinion Deutsch is here confusing "Haftungsgrund" and "Haftungsumfang", although he himself denies this. 
but, rather, pushed aside. Whichever way we look at it, Deutsch is comparing a handicapped life with a healthy life.

In American case law, totally different results have been reached. Only a few judges, almost always in the lower courts, have ruled in favour of the child. In the great majority of the cases, the court rejected the child's claim. Sometimes because, in the opinion of the judge, there was no question of a "legally cognisable wrong" (however, sce under Part III, above); sometimes-as already discussed-because a favourable verdict for the child might be seen as a disqualification of handicapped life; and lastlyand this is the question now being dealt with-because a comparison between a handicapped existence and a healthy existence is not possible. How can we say anything about "non-existence", "the utter void of nonexistence"? "? Similarly, how can we say anything about whether non-existence is "better" than a handicapped existence, or whether the worst life is better than the best death?

In numerous American verdicts it is emphasised that much more is involved than the difficulties of assessing the damage; the "imprecision of damages" is said to be an insufficient reason for rejecting the child's claim. ${ }^{42}$ However, the problem here is literally of a fundamental nature: it affects the very foundations of our concept of damage. It is understandable that a judge, confronted with the injured child, is tempted to pay less heed to the foundations of our liability law. And yet it would seem more courageous to stand firm and reject the claim (but it is easy to be courageous when not in the front line). For judges working in those countries with a strong system of social programmes, it is easier to stand firm knowing that the child will have appropriate medical and educational assistance without bankrupting the parents.

Nonetheless, my conclusion is that the children in wrongful life claims of this type have no right to compensation. Not because the child does not suffer any damage, but because of the lack of the comparison point needed to ascertain the compensation: whichever way you look at it, the child would never have had a healthy life. Under liability law, this child who has been born handicapped should be treated no differently from handicapped people who cannot point to a mistake made by a third party. It is a societal decision of how much to assist all handicapped people. The mistake in itself is insufficient to allow one class of the handicapped to claim special compensation. This applies both to the rubella cases and to those in which careless genetic counselling was given before or during pregnancy. Both types of cases have one thing in common: non-existence

41. Gleitman v. Cosgrove, supran.38 (rubella), the first wrongful life claim. It was rejected and the verdict was to play an important role in numerous other cases in which the claim was rejected (e.g. in McKay, supra n.4).

42. E.g. Turpin v. Sortini, supra n.10. 
was the only alternative for the child. The child-as it now stands before the judge-could never have been "healthy" ${ }^{43}$ On the other hand, if it would have been possible on the basis of careful medical treatment for the child's handicap to have been alleviated, there is a much stronger case for compensation. Incidentally, that future seems to be moving ever closer now that more and more possibilities are opening up in the area of, say, genetic manipulation. But for now, this is not possible: the claim must be rejected. ${ }^{44}$

\section{OTHER GROUNDS FOR REJECTION}

ANYONE who peruses the case law and literature, in Europe and in the United States, on the wrongful life claim will notice that other arguments are also used to reject the child's claim. A number of US judges, for example, have ruled that the child's claim is against public policy. That ruling usually stems from the conviction that it is "unseeming" for someone to throw his or her existence open to public discussion. Nevertheless such (and also other) cases involve a normal claim for compensation, albeit one that is based on exceptional circumstances.

The rejection of the claim may also result from a certain-frequently unexpressed-fear of ethical questions. Such a fear, it is said, would cause a court of law to choose a simpler route, since the court normally has to reach an opinion in a brief space of time as compared to the years available to State commissions and politicians. In the New York case of Becker v. Schwartz, for example, one of the judges considered the wrongful life problem to be a "mystery more properly to be left to the philosophers and the theologians". ${ }^{45}$ Although Dias and Markesinis do refer to the ethical dimension attaching to some medical liability cases as a "God-sent gift" for the lawyer- "it gives his topic an added dimension which other, more black-letter topics simply do not have"-that is surely more likely to be the experience of the researcher rather than of the judge working under great pressure of time. ${ }^{46}$

Another argument raised against the wrongful life claim, inter alia by the Law Commission and by the UK Pearson Commission, was the danger of an increasing number of abortions. ${ }^{47}$ It was thought that, because of a

43. See Weir, op. cit. supra n.27, at pp.227 et seq.

44. I realise that this may seem harsh. And harsh it must also have been in so many other cases where not all the requirements for liability were met, as e.g. (in a completely different case) Barnett $\mathrm{v}$. Chelsea and Kensington Hospital Management Committee [1968] 2 W.L.R. 422. The argument that in this way a doctor "gets off scot free" and that this is undesirable does not appeal to me. The "punitive" function, which liability law scarcely possesses anyway, should be found in such a case in professional disciplinary sanctions.

45. Becker v. Schwartz, supra n.10.

46. R. W. M. Dias and B. S. Markesinis, Tort Law (1989), p.171.

47. Royal Commission on Civil Liability and Compensation for Personal Injury, Report, Vol.1 (1978), Cmnd 7054-I No.1485. 
fear of being held liable, doctors might bring pressure to bear on pregnant women to have an abortion performed if there was the slightest chance that something might be "wrong" with the child. This argument is difficult to follow: most wrongful life claims involve doctors who made mistakes in the information they provided to the woman. If they made no mistakes, they have nothing to fear: the choice whether or not to have an abortion is in fact that of the woman-provided she stays within the limits of the law. A fear of some pressure being brought to bear on the woman is realistic only if mistakes have been made at an earlier stage. But, even in such a case, this argument is still too weak to constitute a rcason to reject a wrongful life claim. If the argument was founded, surely this should rather be a task for the legislature?

The same applies to the fear that claims by children against doctors will be followed by claims by children against their parents. One of the firstand most famous-cases was that of Zepeda v. Zepeda. ${ }^{48}$ A child brought a claim for compensation against his father for having fathered him after making false and unfulfilled promises of marriage to his mother. The child now had to go through life as a "bastard" which, he said, caused him suffering. The Supreme Court of Illinois decided that it was indeed an act of tort on the part of the father; the Court was so afraid of opening the floodgates to subsequent claims, however, that it rejected the claim. Other examples can easily be given: mothers who smoke or drink, pregnant women who endanger the unborn child through, say, reckless driving, and parents-the Bundesgerichtshof specifically mentions them-who opt for a pregnancy despite a not insubstantlal risk of a handicapped child being born ${ }^{49}$ Should cases like this now be an argument for rejecting the child's claim in a completely different case? I think not. They are cases which should be judged on their own merits and in which, above all, the question to be examined is whether or not there has been a violation of the duty as against the child. If there is a fear of the law being abused, then surely this, too, is a task for the legislature. ${ }^{50}$

48 Zepeda v Zepeda, supra $\mathrm{n} 3$ In the US literature this case is sometimes described as "Interfamilıal warfare", sec Bopp, Bostrom and Mckınney, op ctl supra n 38, dt p 511

49 One reason for rejecting these claims may be practical, the claim is not really aganst the parent, but against the insurer

50 Just like the UK legislature with the Congenital Disdbilities (Civil Liability) Act 1976, chap 28 (see supra $\mathrm{n}$ 6), and the legislatures in many States in the US. In Californa e $g$ a wrongful life statute was enacted in response to language in Curlender, supra $\mathrm{n} 10$, which suggested the possibility of wrongful life suits by seriously impared children against their parents "No cause of action arises against a parent of a child based upon the clam that the child should not have been conceived or, if conceived, should not have been allowed to have been born alıve" Cal Civ Code, para 43 6(a) (West, 1981) A more recent development in the US is the "Freind Amendment", introduced by Congressman Steven Freind (42 Pa Cons Stat Ann, paras 8305-8306 (Purdon Supp , 1989)) The law is discussed by $J$ Lyons, "To Be or Not to Be. The Pennsylvania General Assembly Elımınates Wrongful Birth and Life Actions" (1989) 34 Vill L Rev 681 et seq 
Lastly-and this applies specifically to the United States-one important argument for rejecting the claim is found in attempts to contain the medical liability crisis. This argument plays a role mainly for the legislature. In numerous States legislation has been introduced banning the wrongful life claim. The arguments for this legislation are partly of "a higher order", ${ }^{51}$ but express reference is also made to the insurance crisis. One example is the Freind Amendment in the State of Pennsylvania. ${ }^{52}$

\section{CONCLUSION}

LET me now return to the beginning of the article. The Bundesgerichtshof took the view that, by allowing the girl's claim, limits within which the liability law ought to remain would be overstepped. It would not be surprising if lawyers in many other countries felt the same. This article advocates a careful approach to those limits to liability. Appealing to them is dangerous in that it carries an inherent suggestion that this is the natural course of things; for, in fact, limits are usually cognisable and clearly marked. In wrongful life cases this will often only appear to be so: the Bundesgerichtshof's belief that it could identify a limit differs completely from the view taken by numerous individual US judges and numerous authors. The limit will be drawn by everyone in a different place-certainly where matters having an ethical impact are concerned. In this way everyone can do as the Romans did and make sacrifices to his own Terminus, his own god of boundaries.

If this is true, and if such a boundary represents no more than a fragile façade for a highly personal viewpoint, appealing to it serves no purpose. In the same way as between neighbours, boundaries make sense only if they are accepted by more than one person. And is it necessary? Within liability law we already have one clear boundary marker, and that is the requirement of breach of the standard of care: the default, the act of tort. Confining myself for the moment to medical liability, by carefully laying down the duty, by setting no unrealistic requirements for professional practice by doctors, a much more important contribution will be made to keeping the liability "tragbar" (acceptable) than by rejecting or legally prohibiting one comparatively arbitrary type of claim.

I have also argued in this article in favour of a careful handling of the dogmatics of liability law. As an incisive example I chose the dilemma of the wrongful life claim. My conclusion is that the claim by the child must be rejected. Not because no legal obligation has been infringed as against

51. E.g. that it is considered undesirable if parents who (say that they) will opt for an abortion are entitled to compensation, whercas parents who make a "pro-life" choice would have no such entitlement. Some people think that this distinction cannot be justified. In the Freind Amendment, $i b u d$, this is one of the explicit arguments for banning the wrongful life claim.

52. See supra n.50. 
the child; it has been infringed. However, what does stand in the way of liability is the fact that there is a lack of the comparison point required for assessing the compensation of damage. For the child there is only one alternative: non-existence. Although this seems unsympathetic to the child, the choice for or against compensation of damage is at the same time a choice for or against the dogmatics of liability law. By choosing the dogmatics of liability law I have chosen against the child. However, over time the dogmatics have served us well. When a plaintiff has proved all of the required elements, a court's duty is to find the defendant liable. The court is then imposing what we generally deem to be a tolerable burden on the defendant. To subtract judicially an element from the plaintiff's case would impose an intolerable burden on defendants. On the other hand, judicially rejecting a claim that under the traditional dogmatics is legally sufficient imposes an intolerable burden on plaintiffs. In the case of wrongful life, the claim does not fail because "acceptable limits" have been reached. More simply, it fails because the plaintiff is unable to prove all of the traditional elements. If the traditional balance is to be altered in favour of either plaintiffs or defendants, it is up to the legislature to make that change. 